\title{
Spelling Analysis, Effective Sentences and Paragraphs in Student Scientific Papers Applied Bachelor of Bali State Polytechnic
}

\author{
I Nyoman Mandia*, I Nyoman Sukra, Putu Dyah Hudiananingsih \\ Accounting Department \\ Politeknik Negeri Bali \\ Denpasar, Indonesia \\ *nyomanmandia@pnb.ac.id
}

\begin{abstract}
This study aims to determine the level of use of spelling, effective sentences, and Indonesian language paragraphs in scientific papers applied by undergraduate students of the State Polytechnic of Bali in the form of theses. This research is important because there is a tendency to use spelling, effective sentences, and paragraphs in student scientific papers that are not in accordance with applicable rules such as prepositions, punctuation. The method used in this study is a qualitative method, while the method of data collection in the form of documentation with qualitative descriptive analysis. Studies on spelling order, each of them scored: Managerial Accounting Study Program 98.73, International Business Study Program 98.96, Tourism Business Management Study Program 99.02, Construction Management Study Program 98.51 with an average rating of 98.80. At the sentence level each gets a value: Managerial Accounting Study Program 83.72, International Business Study Program 85.22, Tourism Business Management Study Program 77.25, and Construction Management Study Program 74.75, while at the paragraph level each value: Accounting Study Program Managerial 70.74, International Business Study Program 61.20, Tourism Business Management Study Program 60.31, and Construction Management Study Program 66.87, with an average rating of 64.78. Thus, it can be concluded that spelling ability, effective sentence, and student paragraphs applied bachelor of Polytechnic Bali is very good.
\end{abstract}

Keywords—spelling, sentences, paragraphs

\section{INTRODUCTION}

The ability of students to analyse a problem is not just competence in the field of science they occupy, but the mastery of a language including the mastery of spelling, sentences, and paragraphs is a requirement that must be fulfilled by every student, considering language as a means of developing knowledge and as a determinant of the realization of a paper. Good mastery of spelling, sentences, and paragraphs will produce a quality writing and the most important thing is understanding the written work will be easier for readers to understand because the use of the language is not wordy.
At present the written notes of the Bali State Polytechnic students in scientific work have not reflected the expected format of the curriculum on the use of the Indonesian language. In terms of writing (spelling) the use of prepositions in, to, from, still blurred writing, sometimes written as a prefix and on a different side written as a preposition. A broader error is that the effective sentence has not been asked as capital in a paper. In a sentence that is less structured will lead to misinterpretation. Likewise, paragraph formation has not demonstrated the unity of ideas and has not demonstrated the correct harmony of paragraphs.

Sudaryanto stated that Indonesian language rules include spelling rules, word formation rules, rules of sentence arrangement, rules of paragraph arrangement, and rules of structuring reasoning. If spelling is used carefully, the rules of word formation are given careful attention, and the structuring of reasoning is obeyed consistently, the use of Indonesian is said to be correct. Conversely, if the language rules are not adhered to, the use of the language is considered incorrect [1]. Based on the results of student writing assignments, it can be conveyed the forms of writing errors include: (1) scientific language in the sentence structure uses more active forms than passive forms, (2) illogical sentence structures. The pattern of sentences should be written clearly, which shows the subject, predicate, object, or description, (3) excessive clause writing, so it is difficult to distinguish which clause and the parent sentence, (4) prefix removal, which is very disturbing in the application Indonesian structure.

Another thing, from the results of daily tests working on sentences, the average undergraduate student at the Bali State Polytechnic only reached 6.8 , still classified as $c$ and $b$, so it needs to be improved to get a more satisfying grade. However, it cannot be denied that there are some students who get a score of 8.5 and there are also scores of 3.5. In addition, in terms of doing writing / discourse exercises, many student works have not implemented punctuation, correct word choice (diction), sentence structure that does not meet standard criteria, and the use of absorption elements does not meet the correct way of 
absorption of words and terms in accordance with the guidelines for writing absorption elements from both foreign and regional languages.

The tendency of using rules that are not standardized for some students can threaten the survival of good and right Indonesian language in society, even though language is one of the national identities that should be maintained by all members of the community.

Through writing activities students will provide input of various information and knowledge to readers of the results of their writings. The contents contained in the essay tell the relationship of humans to the universe and the relationship between humans. Even though each student has the ability, still has a level of difficulty in learning Indonesian is not considered to be a concern that needs to be considered. This is slightly different from learning which involves the exact sciences, Physics, Mathematics, and others which are considered to have a high level of difficulty. In the end the grades obtained by students in learning Indonesian are no better than learning involving exact sciences. Writing is pouring ideas in the form of words, sentences, paragraphs, which finally form a discourse. Writing activities are an inseparable part in a productive learning process experienced by students.

Good mastery of paragraphs will produce a quality writing and the most important thing is understanding the paper will be easier for readers to understand. Literature about paragraph analysis methods is increasing, including those written in Indonesian, but not necessarily the users of the book can directly practice the method in a scientific study, both in the form of assignments and thesis. From the experience of teaching Indonesian language courses at the Accounting Department of the Bali State Polytechnic, guiding, and testing students who made theses with this method, as well as providing paragraph analysis training, it was concluded that generally students had difficulty applying the use of paragraphs to the research themes they chose.

Writing becomes one of the most important language skills in human life. By writing, a person can transmit or influence the community by using thought or ideas he wrote. It is said that Tarigan wrote that writing was used to report/inform, influence, and intent and such purposes can only be accomplished well by those who can compose and express his mind clearly [2]. This clarity relies on the mind, organization, use of words, and sentence structure. These four must be mastered by an author so that the intent and purpose that he wants to convey can be conveyed well. Writing becomes one of the most difficult language skills when compared to three other skills. It is in accordance with the opinion of Nurgiyantoro that if compared to three other language skills, writing ability is harder to be mastered by native speakers of the language concerned though. This is due to the writing ability to require the mastery of various elements of the linguistic and elements outside the language itself which will be a bouquet [3].
Thus, it is very precise when the potential students in achieving good writing skills are continuously improved. In addition, it is said that writing activities are the most complex language skills. It is because the writing activity should be done by the students after having the skills of reading, listening, and speaking) Nevertheless, writing learning can be done simultaneously with the skills of reading, listening, and speaking.

The above barriers must be experienced by students in writing and reading learning. In order to overcome these matters above, there is no other way for teachers/lecturers to provide training to their students continuously. The reading and writing exercises of course have to be done gradually and continuously. The steps that teachers must do in learning to read and write are reading and writing a single sentence, writing compound sentences, writing paragraphs, and writing essays or discourse by understanding the of elements in the writing of essays or discourse. In addition, practice should be initiated by composing simple, real, and contextual sentences, then followed by more compound, complex and abstract sentences.

In other parts, Suparno argues that writing is an activity of message delivery (communication) using writing language as a tool or media. Writing essay is one of the many activities found in Indonesian language learning at school. The problem, in the writing of many students is unable to determine the topic, composing a framework of the essay, establishing coherence and development of paragraphs, specifying the main sentence in the paragraph, as well as adjusting the alignment of the content to the topic [4].

Student writing activities are currently very rare, because students are reading more text in Google online so that students rely on copying or copy activities rather than making their own sentences or paragraphs. In another case, students have learned Indonesian language since the elementary school should be writing students at the time of making the scientific work has shown the writing that meets the Indonesian language that is good and true but in fact there are still many languages that are not in accordance with the rules that apply, such as: spelling, selection of vocabulary, effective sentences and the unity and the paragraph.

In this study discusses the analysis of spelling writing, effective sentences, and writing paragraphs written in the work of students who wrote the Bali State Polytechnic, which was embodied in the scientific paper thesis. A good paragraph must have a requirement (1) Unity, i.e. the necessity of the paragraph to show, clearly a particular purpose or theme. The unity here cannot be interpreted that it contains only one thing. If there is a distorted sentence of the point of the mind of the paragraph, the paragraph becomes intact. Sentence The deviant must be excluded from the paragraph, and (2) is the paragraph, the good will occur when the reciprocal relationship between sentences that builds a paragraph is good, natural, understandable. In other words, in this case readers can easily understand the way the author's mind. 
The results of the observation, by directly reading the scientific work of the Diploma IV Politeknik Bali State Polytechnic Program as well as the student training results, not all of their papers show the writing system, effective sentences, and paragraphs that are unity and coherence or clergy. Some Paragraph show a unity that leads to a single idea or unity of mind, but has not yet shown coherence or density. In contrast, in some paragraphs shows the density but does not show unity. This research will analyse the student's work in particular the analysis of paragraphs related to unity and the entity which is an absolute requirement in a paragraph.

The value of current student writing skills needs to be improved, although there is insufficient of graduation value. In addition, many students have difficulty in making paragraphs or essays in conducting learning on campus. These are the things that are behind the research with the subject and the object. Based on the background, which is a formulation of the problem in this research is (1) How to spelling the scientific papers applied undergraduate students of Bali State Polytechnic, (2) How to write effective sentences in the scientific papers applied undergraduate students of Bali State Polytechnic, (3) How to unity and the union of the scientific writing paragraph of applied bachelor students of Bali State Polytechnic?

\section{THEORY REVIEW}

In general, the types of errors in spelling research, effective sentences, and paragraphs are as follows:

\section{A. Grammatical Error}

Hasyim in 2012 refers to the analysis of the mistakes shown by students and teachers as important grammatical analyses. He said that with an error of analysis, students could know the difficulties they faced in grammar, and the teacher could tell if they had successfully taught the material. The focus of researchers on this research is on the order of words, verbs, subject-verb agreements, and reference agreements [5].

\section{B. Punctuation Errors}

Arama states that punctuation marks have the same task for facial expressions and body language; They help the reader understand what the actual author means. For this reason, punctuation errors can cause misunderstandings, so students have been trained to use them properly. Researchers from this study focus on basic punctuation because sentences end up like full stop signs, question marks and exclamation marks alongside the use of commas, and commas [6].

\section{Spelling Mistakes}

According to Kusuran, Amir's spelling mistakes are divided into two main categories, typographical errors and cognitive errors. Typographical errors include adding, eliminating, replacing, or transferring letters while cognitive errors including those letters have phonetic similarities, such as "Academic " and "Academic ". However, because spelling mistakes often change the meaning of sentences, and cause misunderstandings, researchers from this study assume all spelling mistakes as cognitive, and they divide the wrong Word into frequently and rarely used words [7].

\section{Coherence Errors}

Ruegg and Sugiyama refer to the coherency of the content organization. Researchers from this study confirmed the importance of its effects in attracting readers ' attention and interest. They train students to pay attention to their writing with introductory sentences supported by explanatory sentences and end with a cover [8].

\section{E. Sentence Error}

This error focuses on the proper use of capital letters, and spatial settings because individuals from the target population are prepared to become English teachers. McFarland refers to the importance of handwriting for the ability of the brain, memory, motor skills, and reading, and emphasizes the importance of this paper in the early stages of teaching children [9].

Baghzou stated that their students repeated the same mistake; They adopted the understanding of Corder, about the similarity between acquiring a native language and learning a foreign language, and about the benefits of using feedback with children only to improve their native language. Here, researchers from this work highly recommend using error analysis as feedback for any foreign language learners [10]

As for the types of mistakes, in general, researchers from this research are the following sub-criteria:

Unlike Yuliana's explanation that there are six patterns of arguments in the argumentative paragraphs in the results and discussion of the article. The six patterns of argumentation are (1) Data position statement pattern; (2) Position statement pattern-Data1-Data2; (3) Data pattern-position statement; (4) Pattern Data1-Data2-position statement; (5) Pattern Data1-Data 2-Data 3-Data 4-Data 5-warranty-position statement; (6) Data pattern 1-Data 2-Position Statement-Data 3-Data 4-Data 5 Thus, it can be concluded that the argument of paragraphs in the results and the exact discussion of the articles of accredited Journal of Economic Field still need to be improved. Fixing paragraphs of linked and matched arguments in the discussion section is crucial and urgent to be done so that Indonesian scientists who contribute scientifically in accredited journal articles can increase their scientific participation in the broader academic arena [11]

Mungungu conducts quantitative research to identify errors made in writing by three groups of Namibia: Oshiwambo, Afrikaans and Silozi. He, then, compares the type and frequency of their mistakes. The samples consist of 360 essays written by 180 participants from various secondary schools in different regions; Each group consisted of 60 people. The focus of research is on mistakes made by participants in the form of words, prepositions, articles, and spelling. Further research suggests that the highest number of mistakes was made by the 
group Oshiwambo, and then the group Silozi; The lowest number of mistakes made by Africans [12].

Sarfraz examined an error of fifty English essays written by fifty undergraduate students of Pakistan. The focus of research is identifying, describing, and evaluating mistakes made by fifty participants. Sarfraz thought that 61 of the 76 errors resulted from the interlanguage process, which implies a bad habit of the learning strategy. In addition, 15 other mistakes are due to maternal language disorder. Sarfraz also considers mistakes due to lack of practice, feedback, motivation and carelessness of the students.

The critical Thinking theory conveyed by Toulmin in the study of Yuliana Setyaningsih was placed as a reference analytical framework to examine the argumentative paragraph patterns in the discussion section of the journal article that became the object of this study. Toulmin's critical Thinking theory to provide solutions, how argumentative paragraphs in the results and discussion sections of accredited journal articles should be improved. As for the argument, Golden insists that "Toulmin's argumentation model is a dynamic model that highlights the movement of rhetoric reasons ". The dynamic argument model of Toulmin allows authors to select the pattern of the arguments required to achieve the desired level of argument understanding.

This was in line with the research conducted by Qin and Karbacak on the application of model argument elements in the English language department students ' argument at a university in China, which found that the position (claim) statement and data needed to be followed by a claim counter, response data, claim contention, and disclaimer data, resulting in a stronger argument.

Kanyakorn Sermsook in an Analysis of Errors in Written English Sentences: A Case Study of Thai EFL Students, the study focuses mainly on sentences because researchers found that Mistake in the sentence construction of the EFL students of Thailand can cause miscommunication. 104 writings written by 26 second-year students of the primary English who enrol in the writing course II are gathered and analysed. The results showed that the most frequent mistakes were punctuation, articles, subject-verb agreements, spelling, capitalization, and fragments, respectively. Interlingual disorders, intralingual disorders, limited knowledge of grammar and English vocabulary, and student carelessness are found to be the main source of the mistake [13].

Ryo Nagataa in Adaptive Spelling Error Correction Models for Learner English, expressing misspelling is characteristic of English learners and lowers the performance of natural language processing systems targeting English learners. This paper describes a method specifically designed to correct spelling mistakes in English for students who reduce the effects of noise (e.g., grammatical and spelling mistakes) by adaptive making the spelling correction model of corporate students. An evaluation suggests that the proposed method is better than the method of editing distance based and previous model-based methods. This research shows the results of an investigation of what kind of misspellings are likely to be done by English learners, using a spelling mistake model created by the proposed method as a tool for analysis [14].

Kyriaki Neophytoua in The Use of Spelling for Variant Classification in Primary Progressive Aphasia: Theoretical and Practical Implications shows a fairly different spelling profile. Given the theoretical and empirical evidence that indicates that spelling can serve as a proxy for spoken language, the study aims to determine whether the spelling performance is only, when evaluated with advanced statistical analysis, allowing for the accurate classification of PPA variants [15].

\section{RESEARCH METHODS}

The descriptive method is done with the intent of the data collected is not processed with words but rather the depth of the passion for the problem discussed [16]. The Data is collected using content analysis with the aim of analysing the spelling, effective sentences, and paragraphs of student scientific work. In addition, this research is in accordance with some features of qualitative design namely: (1) natural setting, (2) human beings as instruments, (3) Qualitative methods, (4) Inductive data analysis, (5) Theory of Basic, and (6) descriptive.

In this section, clearly outlined the type of data collected, the data source, and the techniques used to collect the data. This research Data is a result of scientific writing of students in the form of thesis Diploma IV State Polytechnic school year 2019. The Data needed amounted to 40 student scientific papers. The research will be obtained in the form of paper print reports and is focused on spelling, effective sentences and paragraphs.

The population is the overall subject of research Merill [17]. Population research is done when researchers want to see all the twists in the population. The research population is also expressed as a group of interesting researchers to generalize the research results, or research subjects as a set consisting of people, animals, plants, or objects that have common traits [18]. Based on this the population in this study is the entire student thesis of Diploma IV year 2019 amounting to 413 papers.

Error analysis has become increasingly important, especially in the field of linguistics; Thus, the proliferation of studies using AL-Khasawneh identifies the type of The mistake of writing English paragraphs by 26 Jordanian students from various majors at the Ajloun National University. After grouping errors into an error using the article [19]. Prepositions, subject-verb agreements, word sequences, tense, plurality, spelling, capitalization, sentence structure, demonstrative, and irregular verbs, the highest error frequency is in the use of articles. Al-Khasawneh thinks that such mistakes are done due to inadequate exposure to target languages, lack of practice, and interference.

As demonstrated, most studies consider the reasons of making mistakes in writing with interference between native 
and non-indigenous languages, lack of practice and feedback from the early years of learning in addition to the lack of students ' motivation and prudence in following their teacher's instruction and Internet use. Undoubtedly, the role of teachers, curriculum, and exposure to foreign languages is also important to improve students ' writing skills. For researchers of this work, Salebi's way of letting students comment on their mistakes is a good way to help them recognize mistakes and overcome them. Furthermore, this research is consistently.

This spelling, sentence, and paragraph research is analysed in a qualitative model, while the design of the research is a descriptive method. According to Gay, a descriptive method is used to determine and is based on the students ' weak points to reduce if it does not eliminate such mistakes [20]. Based on records from the Bali State Polytechnic Library, the population of scientific works was 2019 as of 363 . From the population of 363 , the number of samples was determined by 40 thesis or approximately $10 \%$ of the total population.

This research uses methods of observation, which is observing data on spelling writing, effective sentences, and paragraphs of Indonesian language in the scientific paper of applied undergraduate student Polytechnic Bali. This method has the basic technique of sadap technique. The recorded technique is referred to as the basic technique in tapping method.

\section{RESULTS AND DISCUSSION}

The thesis Data of the Managerial accounting study Program was ten copies. Here are some results and discussions of spelling, effective sentences, and paragraph.

According to Arens, stating, "Operational audits are a study of any part of the procedures and methods of operating an organization to assess its efficiency and effectiveness. Generally, during the completion of the operational audit, the auditor will provide some advice to the management to improve the operation of the company. According to Tunggal, stating, "The purpose of the operational audit is to disclose the lack and inconsistency in any element tested by the operational auditor and to demonstrate what repairs are possible..."

The two-sentence fragments of the text are impartial in writing. The word according is the same as the word declare. Thus, the word states no need to be rewritten. For more details, see the following description.

According to Arens, "Operational audits are a study of any part of the procedures and methods of operating an organization to assess its efficiency and effectiveness. In the other part, according to Tunggal, "The purpose of the operational audit is to disclose the deficiencies and irregularities in any element tested by the operational auditor and to demonstrate what improvements are possible..."

In different sections, written spelling as follows.
While according to Sukrisno, "Auditing is an examination made to be critical and systematic by an independent party to the financial statements that have been compiled by the management and bookkeeping records and evidence of its supporters, with the intention of giving opinions on the fairness of the financial statements".

Writing words while at the beginning of sentences or at the beginning of paragraphs is not justified, because the word is a conjunction. The writing is said to be true when it is written with: according to Sukrisno, "Auditing is an examination made to be critical and systematic by an independent party to the financial statements that have been compiled by the management and bookkeeping records and the evidence of its supporters, with the intention of providing opinion on the fairness of the financial statements".

The spelling, sentence, and paragraph capabilities of the managerial accounting study Program can be outlined: the average spelling value is 98.73 , the average sentence of 83.73 , while the average value of a paragraph is 70.74 . Thus, the merging of the average spelling, sentence and paragraph values of 84.40 is very good.

\section{A. Data 2 International Business Study Program}

Of the number of employees is expected to be more helpful to HIS in the operation of the company, so that management activities can run well. In addition, the company must also be able to optimize the various potential owned by all employees, whether it is knowledge and skills work. Because by balanced the performance of the optimal employees will be able to help the company to reach its target.

The word from in the text above shows the subject of the sentence is unclear, because the word of pontension as a description. Similarly, the word for sentence (2) is less precisely placed at the beginning of the sentence. The paragraph above will be correct when written: "The number of employees expected to be more helpful to HIS in the company's operations, so that management activities can run well. In addition, the company must also be able to optimize the various potential owned by all employees, whether it is the knowledge or skill of work. Therefore, by offset the performance of the optimal employees will be able to help the company to reach its target ".

Looking at the chart above, explained that the increase occurred in the beginning of the year 2018 with the sale of products from the company PT Harum Indah Sari Tours \& Travel went well, proved from an increase in January to March of 570. However, the decline in April to June amounted to 579. The following month increased with a sales value of 2312. At the end of the year 2018 product sales from PT Harum Indah Sari Tours and Travel again decreased. Judging from the product sales data of PT Harum Indah Sari Tours \& Travel Pesanggaran is a problem that must be considered by the company to increase the profitability of the company in the future. In addition, employee discipline still often occurs due to weak systems governing the discipline of employees. These 
systems include supervision from the leader as well as sanctions that employees will receive when they are not disciplined. The leadership styles applied in the company also bring influence on employee performance. By applying a leadership style that is appropriate to the condition of the company will certainly make employees ' performance better and increase the company's sales.

The group of words see the above chart, preferably replaced with the chart above shows. Similarly, the initial sentences (3) and (6) should be the second paragraph, because it varies the main idea. More details will be presented with improved spelling, sentences, and pronunciation.

The chart above, explaining the improvement occurred at the beginning of the year 2018 with the sale of products from the company PT Harum Indah Sari Tours \& Travel went well, proved from an increase in January to March by 570 . However, the decline in April to June amounted to 579. The following month increased with a sales value of 2312. At the end of the year 2018 product sales from PT Harum Indah Sari Tours \& Travel again decreased. Judging from the product sales data of PT Harum Indah Sari Tours \& Travel Pesanggaran, is a problem that must be considered by the company to increase the profitability of the company in the future. In addition, employee indiscipline still often occurs due to weak systems governing the discipline of employees. These systems include supervision from the leader as well as sanctions that employees will receive when they are not disciplined.

The leadership styles applied in the company also bring influence on employee performance. By applying a leadership style that is appropriate to the condition of the company will certainly make employees ' performance better and increase the company's sales.

The spelling, sentence, and paragraph capabilities of the International Business Studies Program are not much different than in managerial accounting, each one can be spelled out: The average spelling value is 98.96 , the average sentence of 85.22 , while the average paragraph value is 61.20 . The merging of the average spelling, sentence and paragraph values of the program is 81.79 very good.

\section{B. Data 3 Tourism Business Management Study Program}

Tourism is an industry that has a very large and fast turnover of money. This is due to the increasing interest of the world community to make vacations to many beautiful tourist attractions to visit. Doing a trip, for the world community needs as more and more days of high workloads make the level of stress for employees increasingly, so it takes a routine vacation for employees to remove saturation and back to work with more vibrant circumstances. With such phenomena, many countries start to build a more professional tourism industry and develop the potential in each country-each with the goal of increasing the revenue of the country sourced from the tourists.

Sentence (2) in paragraph above is less grammatical, on the world phrase needs. From the angle of the grammar, the word is still in foreign form, which is the word stress, which should be quite written with stress. It will be more grammatical if the sentence is written "doing a trip for people of the world is a necessity, because more and more days of high workload make the level of stress for employees are increasing, so it takes a routine vacation for employees to eliminate saturation and return to work with a more vibrant state".

Similarly, the third sentence, written in many countries, shows the waste in the word, it should be quite written many countries.

One of the tourism objects that have been successfully developed and become a favourite tourist destination for the world tourists is a tourist attraction in the island of Bali. Bali Island became very famous in the world because the concept that is carried by the government provision Bali is a culture, this is a very unique tourist attraction and able to attract tourists to come to Bali. Besides the natural beauty also encourages the rapid growth of tourism on the island of Bali. Local people also have a large in the development of tourism in the island of Bali, with human resources This is the island of Bali is able to adapt to changes very quickly.

There is a mistake in writing the paragraph above, the first spelling problem, namely the word beside and the island of Bali, which should be on the side and the island of Bali. Secondly, in terms of the less grammatical, "beside the natural beauty also encourages the rapid growth of tourism on the island of Bali". This sentence is not completed, it should be written "beside the natural beauty also that encourages the rapid growth of tourism on the island of Bali, local people also have a big part in the development of tourism. This human resource is able to adapt to a very rapid change. Thirdly, in terms of paragraph should the paragraph in the bag be sorted into two, because the idea of the main paragraph above is different. Here is a different writing of the grammar, sentences, and paragraphs.

"One of the tourism objects that have been successfully developed and become a favourite tourist destination for the world tourists is a tourist attraction in the island of Bali. Bali Island became very famous in the world because of the concept that was carried by the government of Bali province is a culture. This is what is a very unique tourist attraction and able to attract tourists to come to Bali.

In addition to the natural beauty, which also encourages the rapid growth of tourism on the island of Bali, the local people also have a large part in the development of tourism. This human resource is able to adapt to a very rapid change ".

The study of Tourism Business management study Program can each be described as follows: spelling of 99.02, sentence of 77.25 , and paragraph of 60.63 , while merging values of spelling, sentence, and paragraph obtained value 78.86 .

\section{Data 4 Construction Management Study Program}

The liquid waste produced from tofu production has a considerable discharge. If liquid waste knows with a lot of 
discharge this is handled appropriately then the result is not to pollute the surrounding environment. Because of the lack of knowledge of the entrepreneurs know to cultivate the liquid wastewater then the entrepreneurs dispose of waste know in vain. Even entrepreneurs dispose of their liquid waste to the nearest river from its factory site. Then the effect of the discharge of liquid waste is the river becomes dirty and filled with waste. Another effect if the discharge of liquid waste is if it is discovered by the river handle can be penalized and fines are quite heavy.

The conjunctions because and then less precisely placed at the beginning of the sentence, would be more appropriate to be used as a stitch in the intra sentences. For more details, you are presented with the correct writing.

The liquid waste produced from tofu production has a considerable discharge. If liquid waste knows with a lot of discharge this is handled appropriately then the result is not to pollute the surrounding environment. Lack of knowledge of the entrepreneurs know to cultivate the liquid wastewater, so that they dispose of waste in vain. Even entrepreneurs throw the waste of the liquid to the nearest river from its factory site. Therefore, the effect of the discharge of the liquid waste into the river is the river becomes dirty and filled with waste. Another effect is that if it is known by a river handle, it may be subject to penalties and fines that are quite heavy.

In Denpasar area precisely around Tukad Badung, is the place of most tofu factories established. Around Tukad Badung. The area has not been a good environmental management in every factory, so all liquid waste produced, all disposed of in the Tukad Badung. Factory location know that the author is thorough is one of the factories that do not have good environmental management. In fact, if the factory knows it implements a good management system on each manufacturer, then the environment and rivers around are not affected. With the good management system of each factory know then the environment and surrounding rivers are not affected. Therefore, the author is interested to make the problems that exist as a material for the thesis namely the title of management of environmental management in the industry know "John Key" Denpasar Bali"

"As with any error in paragraph data (1), the data in paragraph (2) is needed to be straightened, resulting in good sentences and paragraphs. There is a waste of words or groups of words, namely Tukad Badung written repeatedly, the completeness of the subject and predicate, and the wording of the word that has not been ordered. The following is the alignment of its writing.

In the Denpasar area, precisely around Tukad Badung, is the place of the most established tofu factories. In the area there is no good environmental management in every factory. So, all liquid waste produced, disposed in the Tukad Badung. Factory location know that the author is thorough is one of the factories that do not have good environmental management. Whereas if the factory knows it implements a good management system in each plant, then the environment and rivers around are not affected. "John Key" Denpasar Bali.

Generally, it is made by craftsmen or household industry with simple equipment's and technology. The order of process or the way of making tofu in all small industries know in general is almost the same and if there is a difference only in the working order or the type of protein clot substances used. Soybean raw Material selection is the earliest work in the manufacture of tofu. Good soy is a new or unsaved soy-long warehouse. The new soy can produce good tofu (aroma and shape). To get the know that has good quality, required raw materials of soy seeds are old, the bark is not wrinkled, soybeans do not free from the remnants of plants, gravel, soil, or other grains. The soy used is usually yellow, white, or green and rarely uses a black type of soy. The purpose of this sorting is to keep the know quality well maintained.

The writing of the Aline above is less solid, because the same word is written at the beginning of sentences, such as the soy word. The value of the spelling, sentence, and paragraph elements of the construction management study Program, respectively, can be described: the average spelling value of 98.51 , the average sentence of 74.75 , while the average value of paragraphs is 66.87 . The merging of the average values of the spelling, sentence, and paragraph of the technology program is 80.04 good.

\section{CONCLUSION}

There are three main studies in this study, namely the use of spelling, effective sentence writing, and paragraph writing. According to the previous chapters, the following can be concluded.

Spelling writing is a basic ability in college writing skills. Results of studies of student work, especially in scientific work in the form of a thesis in applied undergraduate students Bali State Polytechnic has been very good. This is shown in the results of the assessment on the 40 samples with their respective scores: Managerial Accounting Department is 98.73, International Business Department is 98.96, Business Management of Tourism Department is 98.96, Business Management of Tourism is .02, Construction Department is 99.02, Construction Management Department 98.96, Business Management of Tourism 99.02, Construction 98.51 with an average rating of 98.80 .

In terms of sentence writing, not much different from the results of spelling ability on four courses, with the acquisition of individual values: Managerial Accounting Department 83.72, International Business Department 85.22, Tourism Business Management 77.25, and Construction Management Department 74.75 .

The assessment result on the paragraph setting obtains an average value of only 64.78, with details: Managerial Accounting Department 70.74, International Business Department 61.20, Tourism Business Management Department 60.31, and Construction Management Department 66.87. Thus, 
the ability of Indonesian language in the field of spelling, effective sentence, and paragraph of applied graduate students of the Bali State Polytechnic is very good, namely with an average value of 81.27 is $\mathrm{A}$ value of $\mathrm{A}$.

\section{REFERENCES}

[1] S. Sudaryanto, Metode Dan Aneka Teknik Analisis Bahasa. Yogyakarta: Duta, 2015.

[2] H.G. Tarigan, Menulis Sebagai Suatu Keterampilan Berbahasa. Bandar Lampung: Angkasa, 2015.

[3] B. Nurgiyantoro, Penilaian dalam Pengajaran Bahasa dan Sastra. Yogyakarta: BPFE, 2015.

[4] S. Suparno and M. Yunus, Keterampilan Dasar Menulis. Jakarta: Universitas Terbuka, 2010.

[5] A. Kusuran, L2 English spelling error analysis: An investigation of English spelling errors made by Swedish senior high school students, 2017.

[6] A. Arama, The Comma and The Period: From Rote Learning To Efficient Classroom Practice: The Case Of Second Year Students. University of Constantine, MA diss., University of Constantine, 2010.

[7] A. Kusuran, English spelling error analysis An investigation of English spelling errors made, 2017.

[8] R. Ruegg and Y. Sugiyama, "Organization of ideas in writing: what are raters sensitive to?,” Lang. Test. Asia, vol. 3, no. 1, pp. 1-13, 2013.

[9] E. Mcfarland, The importance of handwriting: How montessori didactic materials support handwriting, The University of Wisconsin - River Falls, 2015.
[10] B. Sabrina, "The effects of content feedback on students' writing," Ankara Üniversitesi Dil ve Tarih-Coğrafya Fakültesi Derg., vol. 51, no. 2, pp. 169-180, 2011.

[11] Y. Setyaningsih, "Pola Argumen Paragraf Argumentatif Pada Artikel Jurnal Terakreditasi Bidang Ekonomi (Perspektif Stephen Toulmin)," Adab. J. Bhs. dan Sastra, vol. 15, no. 2, p. 136, 2016.

[12] S.S. Mungungu, Error analysis: investigating the writing of ESL Namibian Learners. UNIVERSITY OF SOUTH AFRICA, 2010.

[13] K. Sermsook, J. Liamnimitr and R. Pochakorn, "An Analysis of Errors in Written English Sentences: A Case Study of Thai EFL Students," English Lang. Teach., vol. 10, no. 3, p. 101, 2017.

[14] R. Nagata, H. Takamura and G. Neubig, "Adaptive Spelling Error Correction Models for Learner English," Procedia Comput. Sci., vol. 112, pp. 474-483, 2017.

[15] K. Neophytou, R.W. Wiley, B. Rapp and K. Tsapkini, "The use of spelling for variant classification in primary progressive aphasia: Theoretical and practical implications," Neuropsychologia, vol. 133, no. May, p. 107157, 2019.

[16] L.J. Moleong, Metodologi Penelitian Kualitatif. Bandung: PT Remaja Rosdakarya, 2017.

[17] S. Arikunto, Prosedur Penelitian: Suatu Pendekatan Praktik (Edisi Revisi). Jakarta: Renika Cipta, 2010.

[18] S. Sugiyono, Metode Penelitian Administrasi. Bandung: Alfabeta, 2015.

[19] R.H. Febriyanti and H. Sundari, "Error Analysis of English Written Essay of Higher Efl Learners: a Case Study,” J. English Lang. Stud., vol. 01, no. 02, pp. 2527-7022, 2016.

[20] L.R. Gay, G.E. Mills and P. Airasian, Educational Research Competencies For Analysis And Application. New York: Merill, 2012. 